\title{
Toward Virtual business
}

\section{Emirjeta Bejleri, PhD}

\author{
Lecturer, Department of Business-Administration, \\ Faculty of Economy, University "Luigj Gurakuqi”, Shkoder, Albania
}

Atrida Fishta, MAE

Lecturer (Part-time), Department of Business-Administration, Faculty of Economy, University "Luigj Gurakuqi”, Shkoder, Albania

Doi:10.5901/mjss.2017.v8n3p275

\begin{abstract}
The Internet has provided traditional retailers a new mean with which to serve customers and today there are two main trends of organizations which flow concurrently. On one hand there is the Traditional Organization, established in between 20th century and on the other is Modern Organization emerged in this ongoing century. Many traditional organizations "bricks-andmortar" have transformed to modern organizations "clicks-and-mortar" by incorporating Internet sales. There are huge differences between these two types. On the other hand the appearance of virtual firms raises the question of what kind of changes they have brought to the analysis of a particular industry and in the choice of a strategy for those particular firms and other firms that have to compete with them. The aim of this paper is to explain shortly through a literature review what the brickand-mortar, click-and-mortar and virtual organizations mean and analyzing with three specific examples how does it changes between them the organization structure, the definition of core functions and the degree of outsourcing, use of power and types of bargaining in dealing with suppliers and customers, and key management functions. In the future we believe that this paper will serve as a base for future research in the area.
\end{abstract}

Keywords: brick-and-mortar, click-and-mortar, virtual organizations, organization structure, core functions.

\section{Introduction}

As substantially more consumers have gained Internet access and found it both convenient and secure to shop online, ecommerce has become attractive to more firms (Bernstein et al. 2005). Today the Internet offers to traditional retailers a new mean with which to serve customers and subsequently various Internet enabled business models have appeared. Mostly there are two main trends of organizations which flow concurrently. On one hand there is the Traditional Organization, established in between 20th century and on the other is Modern Organization emerged in this ongoing century. There are huge differences between these two types. Generally the traditional organization represents the organizational structure in a business as hierarchical, meaning power flows vertically and upward, and employees are departmentalized. Always traditional organization is fixed and rigid. Modern Organization means a boundary less organization which are networking together and collaborating more than ever before and is ideal for companies in the growing technology industry.

\subsection{Methodology and Structure}

The methodology of this paper consists in explaining shortly through a literature review what the brick-and-mortar and click-and-mortar mean. Next is explained, using information from literature review, the meaning of the virtual firm and some of their specific characteristics that can change the landscape of the industry market. We have analyzed next, with three specific examples, the changes between these three forms of doing business. We have identified and listed the main differences of these three forms of doing business which consist in the organization structure, the definition of core functions and the degree of outsourcing, use of power and types of bargaining in dealing with suppliers and customers, and key management functions.

This paper is organized as follows. Section 2 presents an overview brick-and-mortar vs click-and-mortar. Section 3 presents an overview of virtual organizations including different virtual organizations' definitions and characteristics. 
Section 4 introduces the three organization's examples that are: one traditional organization in the retail industry which is considered as an Internet enabled brick \& mortar retailer and two competitors a virtual e-retailer and a totally brick \& mortar retailer. Moreover the business environment differences between these forms of doing business are discussed. Finally, conclusions are presented.

In the future we believe that this paper will serve as a base for future research in the area.

\section{Brick-and-Mortar vs Click-and-Mortar}

Many traditional organizations "bricks-and-mortar" have transformed to modern organizations "clicks-and-mortar" by integrating Internet sales. In the case of traditional retailers, the Internet channel is often viewed as a logical extension of the storefront's physical presence, a complement to existing customer relationships, business processes, and distribution systems (Zerega 1999). Especially retailers such as department stores have mostly been influenced by the Internet. They still use their existing retail channels but they use the Internet as a tool to expand their customers share (Bernstein et al. 2005).

Brick and mortar is a traditional form of business that meets and interacts with its customers face to face. Ecommerce researchers have begun to analyze the benefits for retailers of using a combination of online and physical sales channels (Otto and Chung 2000)

Click and mortar is a type of business model that includes both online and offline operations, which typically include a website and a physical store ${ }^{1}$. An important benefit of click and mortar integration is to provide flexibility to customers in the purchase process; this depends heavily on integration of information systems supporting virtual and physical channels (Saeed et al. 2003).

The characteristics of products and services can influence the way an online channel might be used, due to variations in such factors as the physical properties of the product, the value of the product, and the frequency with which the product is purchased (Steinfield et al. 2005).

Usually the creation of a virtual channel can help the organization spread beyond its traditional boarders, reaching new and unexplored markets. Firms' brand name, quality of existing supplier relationships, and possession of a range of other complementary assets, as well as capital and human resources that can be utilized to facilitate its e-commerce (Steinfield et al. 2002).

\section{Virtual Firms}

The appearance of virtual firms raises the question of what kind of changes they have brought to the analysis of a particular industry and in the choice of a strategy for those particular firms and other firms that have to compete with them.

To define more precisely what a virtual organization is, we can consider the following definition provided by DeSanctis and Monge 1999: "A virtual organization is a collection of geographically distributed, functionally and/or culturally diverse entities that are linked by electronic forms of communication and rely on lateral, dynamic relationships for coordination. The virtual organization is a "company without walls" that acts as a "collaborative network of people" working together and the location or who "owns" them is not important. The virtual store becomes a global entity is a new global network created by linking together smaller and existing networks. Internet created an immense opportunity for the organizations and for customers also because now they have the feeling of being part of a large global store. Examples of virtual firms are Drugstore.com which sells health, beauty items and prescription drugs from its website or by telephone and UBid.com which offers customers the chance to participate in online auctions.

The emergence of virtual firms can change the landscape of the industry market because of some of the following specific characteristics of these companies:

- Their nature: They do not have as many constraints as the traditional brick and mortar firms. They have fewer assets, such as buildings for shops, warehouses, etc. They also do not have to worry about the way franchisers run their business.

- Flexibility: Most of the time the virtual companies outsource, so if they want to change business it is easier. They are "reachable" everywhere there is a computer with an Internet connection.

- Capital requirements: Their virtual nature requires low capital to perform their activities, but high investments in information technology are necessary to support direct relationships with supply chain partners.

\footnotetext{
1 Investopedia 2016.
} 
- More focused on the long-term Supplier/partner and customer relationship are critical success factors.

However, on the other hand, a virtual firm has to deal with the traditional constraints as well. If, for example, the competitive advantage of the virtual firm is that they deliver their products on time, they have to rely on their suppliers and their distributors just as much as traditional firms do.

\section{Background}

In order to discuss the differences between the traditional business, click and mortar and virtual organizations we will consider the retailing industry. The retailing industry involves those business activities that sell goods and services to consumers for their individual, family, or domestic use.

Retailing is a highly competitive and dynamic industry. Retail sales are currently at their highest point in history. New technologies are improving retail productivity and globalization is providing even more opportunities. On the other hand, retailers face many challenges. Many customers are bored with shopping or do not have time for it. Some areas have too many stores. As a result, retailers push each other into frequent price-cuttings. Costumer expectations are high and retailers are offering more self-service and automated systems to handle customer interactions. Many retailers are not sure what to do with the Internet, whether they should use it for image purposes, customer information and feedback, and/or sales transactions.

The traditional organization considered in the retail industry is American eagle which is considered as an Internet enabled brick \& mortar retailer and the two competitors considered are alloy.com a virtual e-retailer, and Aeropostlate, a totally brick \& mortar retailer.

\subsection{American Eagle Outfitters}

American Eagle Outfitters, Inc. is a specialty retailer of casual apparel, accessories, and footwear for men and women between the ages of 16-34. The first American Eagle Outfitters store was opened in the United States in 1977 and the brand was expanded into Canada in 2001. As of January 30, 2016, they operated 949 American Eagle Outfitter brand stores and 97 stand-alone and 67 side-by-side Aeries stores located in shopping malls, lifestyle centers and street locations in in the United States, Canada, Mexico, Hong Kong, China, the United Kingdom and internationally².

On April 7, 1999, the company completed a plan of reorganization to achieve certain corporate objectives and to implement a holding company structure and after this reorganization the company name was changed to American Eagle Outfitter, Inc. American Eagle Outfitters design, market, and sell their own brand of clothing, providing high quality merchandise at reasonable prices.

American Eagle is in the specialty retail apparel business and is affected by changes in the economy and customer preference (fashion trends and season). Inventory must be ordered far in advance of the season and this has a direct effect on their inventory levels and costs. The average cost of inventory includes design and sourcing costs and related expenses. Their business is also cyclical in nature and about $60.4 \%$ of their annual sales occurring during the Christmas season and during the back to school period. End of season, overstocks, and irregular merchandise is sold to liquidators below cost. Because their business is somewhat cyclical in nature, they must contend with peak selling seasons. Their long-term goal is better merchandise planning and allocation, inventory flow, and targeted email marketing and site enhancement.

Critical Factors for the Company's Success:

- Forecast and react to changing consumer preferences and fashion trends as quickly as possible.

- Obtain suitable sites for new stores at acceptable costs and successfully acquire and integrate other businesses.

- Expansion of buying and inventory capabilities and availability of capital.

- Interruption in flow of merchandise from key vendors and interruption of services from distribution centers.

Allocation of Merchandise Based Upon:

- Geographic location

- Customer demographics

- Store size

- Store location is crucial in this industry

2 "AEO" finance.yahoo.com. Retrived 14 April 2016. 
The company is vulnerable to:

- Variations in consumer demand

- Pricing changes

- Timing and variety of merchandise purchases

- Merchandise markdowns (used to manage inventory flow) - has an adverse effect on earnings

\subsection{Competitors}

The two competitors in the retail industry that we chose were alloy.com a virtual e-retailer, and Aeropostlate, a brick \& mortar retailer. It is:

- Very competitive industry

- Compete on quality, service, price, fashion, and selection.

- Also compete with casual apparel and footwear departments. Square footage is an important consideration in this industry.

- Differences in the business environment

\subsubsection{Alloy.com}

Alloy is a media, direct marketing, and marketing services company targeting Generation $\mathrm{Y}$ boys and girls in the United States between the ages of 10-243. Their business integrates direct mail catalogs, print media, web sites, on-campus marketing programs, and promotional events. Alloy's the first catalog, was introduced in 1997. The catalog offers a variety of apparel, footwear, accessories, and room furnishings that appeal to Generation Y girls. Their CCS catalog, which was acquired in July 2000, targets Generation Y boys and offers footwear and accessories, an assortment of actions sports equipment and related apparel. Their Dan's Comp catalog was acquired in September 2001 and also targets Generation $Y$ boys. It focuses on bikes, parts, and safety equipment, as well as related apparel, footwear, and accessories.

Each catalog also has a corresponding website that is targeted at the same market as the catalog. Everything that is offered in the catalog can also be found on the website and orders can be placed through the website. They also offer a variety of other features on their websites geared toward Generation $Y$ and their database is enlarged through these sites. They have a private colleges and universities website, and an eStudentLoan site. In our analysis, we will focus on alloy.com. All of their stores are in prime location shopping malls.

\subsubsection{Aeropostale, Inc}

Aeropostale is a fast-growing, mall-based specialty retailer of casual apparel and accessories that target both young women and young men aged 11-204. Their target market is considered the same target as Alloy. Aeropostale provides its customers with a attentive selection of high quality fashion basic merchandise at affordable prices in an entertaining store environment. Aeropostale's products can be purchased only in their stores. The first Aeropostale store was opened in 1987. As of March 30, 2015, the company operates 860 stores in US, Canada and outside the US. It has grown from 119 stores in 1999 to the 860 in $2015^{5}$.

Aeropostale is becoming increasingly popular on the campus scene because of its sponsorships across the country. An updated varsity look has been developed within the clothing line. Their athletic styling has been adapted to what today's youth is shopping for.

\subsection{Business environment differences}

Definition of core functions and degree of outsourcing

- In the traditional organization the core functions are broadly defined. The organization of the enterprise is well defined (hierarchy of jobs). Outsourcing is a question of strategy (tradeoff between being fiscally prudent or protecting the company's expertise protected).

\footnotetext{
3 http://www.alloyapparel.com/about-us/company-bio/

${ }^{4}$ Aeropostale, From 10-K, Annual Report, Filing date March 30, 2015. Sec.gov. Retrived September 26, 2015.

${ }^{5}$ Aeropostale, From 10-K, Annual Report, Filing date March 30, 2015. Sec.gov. Retrived September 26, 2015.
} 
- In the click and mortar organization core functions are still broadly defined, but some functions are protected, especially the web part.

- In the virtual organization core functions narrowly defined 6 . Most of the activities are outsourced, which gives the virtual firm one of its core competency: flexibility.

Use of power and types of bargaining in dealing with suppliers and customers:

- In the traditional organization the rule is that those who have the power use it with distributive bargaining to get the most advantageous conditions. On the other hand, they can also believe in integrative bargaining (this is the case with companies working in vertical integration).

- In the click and mortar organization the rule here also is that those who have the power use it with distributive bargaining. The fact that firms are internet enabled can lead them to two things: if they share some information via the web (EDI, extranet...), this can be a threat for them (their suppliers can get information that would give their firm an advantage) or that can encourage the firm to work in a more cooperative way.

- In the virtual organization power is used in a cooperative and integrative way. The success of a virtual firm highly depends on its suppliers. Since most of the virtual firms outsource, they have to rely on what their suppliers are doing. This means that the virtual firms have to not only monitor what their suppliers are doing, but also provide them what they need to better understand and supply what the virtual firms require.

- Key management functions:

- In the traditional organization the key management functions are to standardize, monitor and control.

- In the click and mortar organization the key management functions are to standardize and control.

- In the virtual organization the key management functions are to monitor, coordinate, and develop alliances with suppliers, even competitors. The purpose here is to create value in the value chain. Besides, these companies are mainly young and have young managers. The management functions are not as defined as they are in a traditional company (in start-ups, employees tend to assume different functions). Their way of working seems more collaborative which seems to encourage integrative bargaining.

The following table can help us to visualize the differences among the three kinds of enterprises that are present in the current business environment: Brick and mortar, click and mortar, and virtual firms:

\begin{tabular}{l|l|l|l}
$\begin{array}{l}\text { Structure of the } \\
\text { organization }\end{array}$ & $\begin{array}{l}\text { Type of Organization } \\
\text { Traditional organizations -Brick } \\
\text { and Mortar } \\
\text { (ex: Aeropostale) }\end{array}$ & $\begin{array}{l}\text { Click and Mortar } \\
\text { (ex: American Eagle) }\end{array}$ & $\begin{array}{l}\text { Virtual Organizations } \\
\text { (Ex: Alloy.com) }\end{array}$ \\
\begin{tabular}{ll|l} 
Definition of core \\
functions and degree of \\
outsourcing
\end{tabular} & $\begin{array}{l}\text { Core functions broadly defined. } \\
\text { Outsourcing is a question of } \\
\text { strategy }\end{array}$ & $\begin{array}{l}\text { Core functions still broadly } \\
\text { defined, but some functions } \\
\text { are protected, especially the } \\
\text { web part. }\end{array}$ & $\begin{array}{l}\text { Core functions narrowly defined. } \\
\text { Most of the activities are outsourced. }\end{array}$ \\
$\begin{array}{ll}\text { Use of power and types of } \\
\text { bargaining in dealing with } \\
\text { suppliers and customers }\end{array}$ & $\begin{array}{l}\text { The rule is that those who have the } \\
\text { power use it with distributive } \\
\text { bargaining to get the most } \\
\text { advantageous conditions. }\end{array}$ & $\begin{array}{l}\text { The rule here also is that } \\
\text { those who have the power } \\
\text { use it with distributive } \\
\text { bargaining. }\end{array}$ & $\begin{array}{l}\text { Power is used in a cooperative and } \\
\text { integrative way. The success of a } \\
\text { virtual firm highly depends on its } \\
\text { suppliers. }\end{array}$ \\
\hline $\begin{array}{l}\text { Key management } \\
\text { functions }\end{array}$ & $\begin{array}{l}\text { Standardize, monitor and control } \\
\text { Standardize and control }\end{array}$ & $\begin{array}{l}\text { Monitor, coordinate, and develop } \\
\text { alliances with suppliers, even } \\
\text { competitors. The purpose here is to }\end{array}$ \\
\hline
\end{tabular}

\section{Conclusions}

The appearance of virtual firms raises the question of what kind of changes they have brought to the analysis of a particular industry and in the choice of a strategy for those particular firms and other firms that have to compete with them.

The emergence of virtual firms can change the landscape of the industry market because of some of the following specific characteristics of these companies such as their nature, flexibility, lower capital requirements, and are more focused on the long-term, supplier/partner and customer relationship are critical success factors.

${ }^{6}$ Core functions specific to a virtual firm would be the Webmaster function, for instance. This competence has to be well defined, because it is thanks to the work of the Webmaster that the virtual firm "comes to life" for the customers. 

relation with:

Mostly business environment differences between the three business forms taken in the consideration are in

- Definition of core functions and degree of outsourcing.

- Use of power and types of bargaining in dealing with suppliers and customers.

- Key management functions

\section{References}

Aeropostale, From 10-K, Annual Report, Filing date March 30, 2015. Sec.gov. Retrived September 26, 2015

"AEO" finance.yahoo.com. Retrived 14 April 2016.

Bernstein F., Song J., \& Zheng X., 2005, "Bricks-and-Mortar" vs. "Clicks-and-Mortar": an Equilibrium Analysis, https://faculty.fuqua.duke.edu/ fernando/bio/Bernstein-Song-Zheng.pdf

Brick and Mortar retrived november 14, 2016. http://www.investopedia.com/terms/b/brickandmortar.asp\#ixzz4PvxcWsbk

DeSanctis G., Monge P., (1999) Introduction to the Special Issue: Communication Processes for Virtual Organizations, Organization Science Vol 10 issue 6. 693 - 703 Published Online: December 1, 1999. http://www.dx.doi.org/10.1287/orsc.10.6.693

Otto, J. and Chung, Q. (2000) 'A Framework for Cyber-Enhanced Retailing: Integrating E-Commerce Retailing with Brick and Mortar Retailing', Electronic Markets 10(4): 185-91.

Saeed, K. A., Grover, V. and Hwang, Y. (2003). 'Creating Synergy with a Clicks and Mortar Approach', Communications of the ACM 46(12): 206-12.

Steinfield, C., Adelaar, T., and Liu, F. (2005). Click and Mortar Strategies Viewed from the Web: A Content Analysis of Features Illustrating Integration Between Retailers' Online and Offline Presence. Electronic Markets, 15(3), 199-212.

Steinfield, C., Adelaar, T. and Lai, Y-J. (2002) 'Integrating Brick and Mortar Locations with E-Commerce: Understanding Synergy Opportunities', Proceedings of the Thirty-Fifth Annual Hawaii International Conference on Systems Sciences, Big Island, Hawaii: IEEE Computer Society.

Zerega, B. 1999. Getting Virtual. Red Herring. September 1999, 124

http://www.alloyapparel.com/about-us/company-bio/ 